\title{
Analisis Penerapan Metode Dakwah Berdasarkan Karakteristik Mad'u dalam Aktivitas Dakwah
}

\author{
Oleh : Rahmatullah ${ }^{1}$ \\ Jurusan Bimbingan Penyuluhan Islam \\ IAIM Sinjai
}

\begin{abstract}
Abstrak: Penerapan metode dakwah dalam aktivitas dakwah harus sesuai dengan karakteristik mad'u yang dihadapi. Pemilihan dan penentuan metode dakwah semestinya mempertimbangkan berbagai aspek terutama tingkat pemahaman dan cara penerimaan dari mad'u. Masyarakat berpendidikan, cendikiawan atau golongan khawas pasti berbeda penerimaannya dengan masyarakat pertengahan dan masyarakat awam. Tingkatan penerimaan dan pemahaman masyarakat yang menjadi mad'u mengindikasikan pentingnya pemilihan metode dakwah yang dilakukan dalam aktivitas dakwah. Secara garis besar dalam al-Qur'an Surat An-Nahl 125 telah dijelaskan tentang metode-metode dakwah yang telah dikaji oleh beberapa ahli tentang kesesuaian antara metode dakwah yang diberikan dengan karakteristik mad'u yang merupakan sasaran dakwah. Metode bi al-hikmah sebagai metode yang utama secara garis besar diarahkan kepada masyarakat cendikiawan atau khawas, penerapan metode mauidzah hasanah kepada masyarakat pertengahan dan metode almujadalah untuk masyarakat awam (masyarakat yang masih dikungkung oleh tradisi jahiliah yang terkadang dengan kesombongannya melakukan kebatilan secara terang-terangan).
\end{abstract}

\section{Keywords: Metode dakwah dan karakteristik mad'u.}

\section{PENDAHULUAN}

\section{A.Latar Belakang Masalah}

Risalah Islam adalah risalah tentang keselamatan dan kebahagiaan manusia dunia dan akhirat, tetapi tidak semua manusia menyadarinya bahkan ada yang berpura-pura mengabaikannya. Sikap apatis atau pengabaian masyarakat akan aktivitas dakwah sesungguhnya disebabkan oleh beberapa faktor di antaranya adalah karena penerapan metode dakwah yang kurang sesuai.

Metode dakwah adalah salah satu komponen dakwah yang sangat penting diperhatikan dan dianalisis kesesuaiannya dengan mad'u. Penyampaian pesan-pesan dakwah yang tidak sesuai dengan kondisi objektif mad'u kerap kali menjadikan mad'u tidak betah bahkan menjauh dari majelis-majelis ilmu agama. Menyampaikan pesan-pesan agama

\footnotetext{
${ }^{1}$ Dosen Tetap IAI Muhammadiyah Sinjai 
dengan ketus dan menyakitkan atau melakukan tindakan yang berlawanan dengan yang disampaikan adalah beberapa hal yang kerap kali ditemukan dan menjadi indikator menjauhnya mad'u dari majelis-majelis ilmu agama.

Fenomena ketidakbetahan dan menjauhnya mad'u dari majelis-majelis ilmu agama menggambarkan tentang pentingnya pemilihan dan penerapan metode dakwah yang sesuai dengan kondisi objektif mad'u. Pemilihan dan penerapan metode dakwah yang sesuai dalam menyampaikan risalah Islam kepada umat manusia diharapkan efektif menjadikan mad'u mau mendekat dan mempelajari ilmu-ilmu agama. Keinginan mad'u untuk mempelajari, mengetahui, mengerti dan memahami ilmu-ilmu agama selanjutnya mengaplikasikan dalam kehidupan sehari-hari merupakan suatu indikator keberhasilan penerapan metode dakwah yang dilakukan.

Harapan akan terwujudnya efektivitas dakwah dengan fenomena problematika dakwah yang banyak ditemukan mengindikasikan bahwa orang yang bergelut dalam bidang dakwah haruslah orang-orang yang berkompeten dan profesional. Pentingnya kedalaman ilmu dari para aktivis dakwah dikarenakan oleh aktivitas dakwah membutuhkan ilmu untuk mengatur dan menata proses dakwah agar lebih efektif dan efisien. Salah satu cakupan ilmu yang harus dimiliki adalah pengetahuan dan pemahaman tentang metode dakwah.

Kebutuhan terhadap ilmu yang terkait dengan aktivitas dakwah seperti metode dakwah dikarenakan oleh ragam karakteristik mad'u. Karakteristik mad'u yang berbeda membutuhkan pengetahuan dan pemahaman dari aktivis dakwah, agar mampu memilih dan mencari metode yang tepat untuk diterapkan dalam menyampaikan risalah Islam. Penerapan metode yang sesuai memberikan harapan bahwa pesan-pesan dakwah yang disampaikan dapat diterima dengan baik serta dapat dipahami dan diaplikasikan dalam kehidupan nyata.

\section{B. Rumusan Masalah}

Berdasarkan latar belakang masalah yang telah dikemukakan, maka hal yang menjadi fokus dalam penelitian ini adalah:

1. Bagaimana urgensi metode dakwah dalam aktivitas dakwah? 
2. Bagaimana karakteristik mad'u dalam aktivitas dakwah?

3. Bagaimana bentuk penerapan metode dakwah berdasarkan karakteristik mad'u?

\section{PEMBAHASAN}

\section{Tinjauan tentang Metode dan Objek Dakwah}

\section{A. Urgensi Metode Dakwah dalam Aktivitas Dakwah}

Dakwah merupakan suatu aktivitas yang tidak dilakukan secara insidentil dan asalasalan melainkan suatu aktivitas yang dilakukan secara sistematis, komprehensif dan disertai dengan persiapan-persiapan yang matang bila menginginkan hasil yang memuaskan, dengan kata lain apabila dakwah diharapkan dapat berhasil dalam proses pelaksanaannya maka hendaklah dilakukan sebaik mungkin.

Asep Muhiddin dan Agus Ahmad Safei seperti dikutip Nurhidayat Muhammad Said menyatakan bahwa dakwah adalah usaha perubahan ke arah yang lebih baik dari situasi sebelumnya, dimana dakwah tersebut sangat erat kaitannya dengan perbaikan (ishlah), pembaruan (tajdid) dan pengembangan termasuk perbaikan pemahaman, cara berpikir dan bersikap. Dari pemahaman yang sempit dan kaku berubah menjadi berwawasan luas dan inklusif. Dari aktivitas yang tidak bermanfaat berubah menjadi aktivitas yang bermakna atau bermanfaat baik bagi kepentingan pribadi maupun kepentingan bermasyarakat. Semuanya ini sangat berkaitan dengan metode pengembangan dakwah untuk mewujudkan kegiatan dakwah yang antisipatif, kreatif dan dinamis. ${ }^{2}$

Menganalisa pengertian dakawa tersebut memunculkan suatu kesimpulan kalau tujuan dakwah adalah menghendaki adanya perubahan. Namun untuk mendapatkannya diperlukan suatu metode yang tepat. Hal ini sesuai dengan pendapat Abu Bakar Aceh seperti dikutip Totok Jumantoro bahwa dakwah adalah;

Perintah mengadakan seruan kepada semua manusia untuk kembali dan hidup sepanjang ajaran Allah yang benar, dilakukan dengan penuh kebijaksanaan dan nasihat yang baik.

\footnotetext{
${ }^{2}$ Nurhidayat Muhammad Said, Dakwah \& Efek Globalisasi Informasi (Cet I, Makassar: Alauddin University Press, 2011), h. 80.

${ }^{3}$ Totok Jumantoro, Psikologi Dakwah: Dengan Aspek-Aspek Kejiwaan Yang Qur'ani (Cet.1, Penerbit Amzah, 2001), h.18.
} 
Pendapat tentang pengertian dakwah yang lain adalah dari Syekh Ali Bin Shalih AlMursyid yang menyatakan bahwa;

Dakwah adalah system yang berfungsi menjelaskan kebenaran, kebajikan, dan petunjuk (agama), sekaligus menguak berbagai kebatilan beserta teknik dan metodenya melalui sejumlah teknik, metode, dan media yang lain ${ }^{4}$

Analisis dari beberapa pendapat ahli tentang definisi dakwah, mengindikasikan pentingnya metode dakwah dalam aktivitas dakwah. Hal ini dapat dipahami karena AlQur'an sebagai kitab dakwah telah meletakkan prinsipnya bahwa manusia yang dihadapi (mad'u) adalah makhluk yang terdiri atas unsur jasmani, akal, dan jiwa sehingga ia harus dilihat dan diperlakukan dengan keseluruhan unsur-unsurnya secara serempak dan simultan, baik dari segi materi maupun waktu penyajiannya. ${ }^{5}$

Beberapa pendapat yang telah dibahas menggambarkan bahwa keberhasilan dakwah terkait erat dengan pengetahuan dan keilmuan da'i, utamanya ilmu tentang pemahaman pada kondisi mad'u yang akan dihadapi yang dengannya dapat ditentukan materi dan metode apa yang harus terapkan untuk menghadapinya.

\section{B. Mad'u dan Karakteristiknya}

Objek dakwah atau sasaran dakwah dalam bahasa dakwah biasa juga disebut dengan mad'u. Kata mad'u ini secara etimologi berasal dari Bahasa Arab, diambil dari bentuk isim maf'ul (kata yang menunjukkan objek atau sasaran). Sedangkan pengertian mad'u menurut terminologi adalah orang atau kelompok yang lazim disebut dengan jemaah yang sedang menuntut ajaran agama dari seorang da'i, baik mad'u itu orang dekat atau jauh, muslim atau non muslim, laki-laki atau perempuan. ${ }^{6}$

Mad'u (objek dakwah) merupakan individu-individu atau orang-orang yang memiliki karakter yang berbeda. Agar materi dakwah yang disampaikan bisa diterima dengan baik,

${ }^{4}$ Moh.Ali Azis, Ilmu Dakwah, Edisi Revisi (Cet.2, Jakarta:Kencana, 2009), h. 11.

${ }^{5}$ Asep Muhyiddin Dan Agus Ahmad Safei, Metode Pengembangan Dakwah (Cet.1, Bandung: Pustaka Setia, 2002), h.75.

${ }^{6}$ Wahidin Saputra, Pengantar Ilmu Dakwah (Cet. 1, Jakarta; Raja Grafindo Persada, 2011), h. 279. 
maka pengetahuan tentang mad'u dengan segala karakternya sangat penting. Secara psikologis manusia sebagai objek dakwah dapat dibedakan oleh berbagai aspek, yaitu;

1. Sifat-sifat kepribadian (personality traits) yaitu sifat-sifat manusia seperti penakut, pemarah, suka bergaul, peramah, sombong, dan sebagainya.

2. Inteligensi yaitu aspek kecerdasan seseorang yang mencakup kewaspadaan, kemampuan belajar, kecepatan berpikir, kesanggupan untuk mengambil keputusan yang tepat dan cepat, kepandaian menangkap dan mengolah kesan-kesan atau masalah, dan kemampuan mengambil kesimpulan.

3. Pengetahuan (knowledge)

4. Keterampilan (skill)

5. Nilai-nilai (values)

6. Peranan (roles). ${ }^{7}$

Ada Beberapa karakteristik objek dakwah menurut Al-Gazali seperti dikutip Malik Idris yang menyatakan bahwa, umat manusia terbagi tiga golongan, yaitu;

1. Kaum awam, yakni kaum yang daya akalnya sederhana, memiliki ciri berpikir yang sederhana, sehingga mereka tidak dapat menangkap hakekat-hakekat mereka mempunyai sifat lekas percaya dan penurut. Golongan ini harus dihadapi dengan sikap member nasihat atau petunjuk

2. Kaum pilihan, yakni kaum yang memiliki daya akal yang kuat dan mendalam, tajam dan berfikir secara mendalam sehingga mereka harus didekati dengan sikap menjelaskan hikmah-hikmah.

3. Kaum penengkar, yakni kaum yang harus dihadapi dengan mujadalah ${ }^{8}$

Adapun menurut pendapat Wahidin Saputra, objek dakwah terbagi atas;

${ }^{7}$ Faizah dan Lalu Muchsin Effendi, Psikologi Dakwah (Cet.2, Jakarta: Kencana, 2009), h. 72.

${ }^{8}$ Malik Idris, loc. cit, h. 51. 
1. Sasaran yang menyangkut kelompok masyarakat dilihat dari segi sosiologis berupa masyarakat terasing pedesaan, kota besar dan kecil serta masyarakat di daerah marginal dari kota besar.

2. Sasaran yang menyangkut golongan masyarakat dilihat darai sudut kelembagaan berupa masyarakat, pemerintahan dan keluarga.

3. Sasaran berupa kelompok dilihat dari segi sosial kultural berupa golongan priyayi, abangan dan santri (dalam masyarakat jawa).

4. Sasaran yang berhubungan dengan golongan masyarakat dilihat dari segi okupasional (profesi dan pekerjaan) berupa golongan petani, pedagang, seniman, buruh, pegawai negeri (administrator).

5. Sasaran yang menyangkut golongan masyarakat dilihat dari segi tingkat hidup social ekonomi berupa golongan orang kaya, menengah, dan miskin.

6. Sasaran yang menyangkut kelompok masyarakat dilihat dari jenis kelamin berupa golongan pria dan wanita.

7. Sasaran yang berhubungan dengan golongan dilihat dari segi khusus berupa golongan masyarakat tunasusila, tuna wisma, tuna karya, narapidana. ${ }^{9}$

Berbagai pendapat yang dikemukakan di atas memberikan gambaran tentang objek dakwah dari berbagai aspek baik dari aspek psikologis, pekerjaan, jenis kelamin, dan beberapa aspek-aspek lainnya. Segala aspek-aspek yang berkaitan dengan objek dakwah inilah yang membutuhkan metode dakwah yang berbeda dan hal ini pulalah yang menyebabkan perlunya mengetahui dan memahami karakteristik dari mad'u.

\section{Analisis Metode Dakwah}

\section{Definisi Metode Dakwah}

Istilah metode dalam bahasa Inggris disebut method, berasal dari Bahasa Yunani "methodos" yang berarti rangkaian yang sistematis dan merujuk kepada tata cara yang sudah dibina berdasarkan rencana yang pasti, mapan dan logis 10

\footnotetext{
${ }^{9}$ Wahidin Saputra, loc.cit, h. 280.
} 
Metode dari segi bahasa berasal dari dua kata yaitu meta (melalui) dan hodos (jalan, cara). Dengan demikian dapat dikatakan bahwa metode adalah cara atau jalan yang harus dilalui untuk mencapai suatu tujuan.

Dalam kamus bahasa Indonesia metode diartikan sebagai;

cara kerja yang bersistem untuk memudahkan pelaksanaan suatu kegiatan guna mencapai tujuan yang ditentukan atau cara teratur yang digunakan untuk melaksanakan suatu pekerjaan agar tercapai sesuatu yang dikehendaki.

Adapun pengertian dakwah menurut beberapa ahli diantaranya seperti pendapat syekh Ali Mahfudz yang menyatakan bahwa;

dakwah adalah mengajak manusia untuk mengerjakan kebajikan dan mengikuti petunjuk, menyuruh mereka berbuat baik dan melarang mereka dari perbuatan jelek agar mendapat kebahagiaan dunia akhirat. ${ }^{12}$

Beberapa pengertian yang telah dibahas menggambarkan suatu kesimpulan bahwa metode dakwah adalah suatu cara yang bersistem yang digunakan dalam aktivitas dakwah, atau dakwah yang dilakukan secara sistematis dengan menggunakan strategi tertentu sesuai dengan kondisi mad'u demi tercapainya efektivitas dakwah.

\section{Ragam Metode Dakwah dan Kesesuaian Arah Penerapannya}

Melihat dan mengkaji fenomena kehidupan dewasa ini, mengantarkan pada suatu kesimpulan bahwa tantangan dan peluang dakwah sudah tidak seimbang lagi. Seorang da'i (aktivis dakwah) penting untuk mengetahui dan memahami berbagai tantangan dakwah di masyarakat agar dapat menentukan langkah penanganannya.

Tantangan dakwah yang dihadapi dewasa ini merupakan masalah besar dan kompleks, karena persoalan yang muncul tidak hanya secara alamiah atau konvensional, melainkan didukung oleh faktor ilmu pengetahuan, teknologi, dan semakin mengglobalnya

\footnotetext{
${ }^{10}$ Malik Idris, Ibid, h. 59.

${ }^{11}$ Departemen Pendidikan Nasional, loc. Cit, h. 740.

${ }^{12}$ Wahidin Saputra, loc.cit, h. 242.
} 
masalah dunia. ${ }^{13}$ Untuk lebih mengetahui dan memahami tantangan-tantangan dakwah tersebut, maka dapat dilihat dari berbagai perspektif, yaitu;

a. Perspektif perilaku, salah satu tujuan dakwah adalah terjadinya perubahan perilaku (behavior change) pada masyarakat yang menjadi objeknya, kepada situasi yang lebih baik. Disini diperlukan strategi dakwah dengan pendekatan teori komunikasi yang tepat.

b. Tantangan dakwah perspektif transmisi (transmissional perspective), dakwah diartikan sebagai proses penyampaian atau transmisi ajaran agama Islam dari dai sebagai sumber kepada madu agar dapat bersikap dan bertingkah laku sesuai ajaran agama yang diterimanya.

c. Tantangan dakwah perspektif interaksi. Yaitu masyarakat yang menjadi objek dakwah pasti berinteraksi dengan pihak-pihak lain atau masyarakat sekitarnya, bahkan masyarakat dunia yang mungkin membawa pesan-pesan lain yang tidak Islami.

d. Tantangan dakwah perspektif transaksional. Adanya perbauran antara peradaban barat dan timur yang ditemukan dalam berbagai aspek kehidupan. ${ }^{14}$

Berbagai macam tantangan dakwah tersebut membutuhkan kerja keras dari para dai/daiah untuk merealisasikan pesan-pesan dakwahnya. Kecerdasan dan ketepatan antara materi dan metode dengan kondisi mad'u harus berpadu, agar dakwahnya bisa efektif dan efisien.

Seorang muballigh atau dai harus pandai dan cerdik serta jeli melihat jemaah yang dihadapinya karena masyarakat atau jemaah yang dihadapi memiliki berbagai macam watak dan pandangan sesuai dengan tingkat pemahaman masing-masing ${ }^{15}$

Menghadapi karakteristik mad'u yang beragam memerlukan penerapan metode dakwah yang sesuai. Secara garis besar metode dakwah dijelaskan dalam Al-Qur'an surat

\footnotetext{
${ }^{13}$ Malik Idris, op.cit, h. 91.

${ }^{14}$ Malik Idris, Ibid, h. 94-115.

${ }^{15}$ Muliaty Amin, Teori-Teori Ilmu Dakwah (Cet.1, Makassar: Alauddin Press, 2011), h. 30.
} 
An-Nahl 125, dari ayat ini pun para da'i dapat menarik pelajaran dari definisi (An-Nahl) yang berarti lebah. Lebah dan kehidupannya yang apabila dianalisa dan dicermati dapat memberikan pembelajaran tentang kehidupan lebah yang selalu hinggap di pohon yang berbunga dan selalu mengisap sari-sari yang bersih dan berenergi, pohon dan ranting yang dihinggapinya tidak terusik, malah hinggapnya lebah ini berguna untuk proses pembuahan dari bunga pada pohon itu. Inilah suatu analogi kehidupan lebah dengan seorang da'i yang senantiasa selektif dalam memilih sesuatu dari segi legal, halal, bersih, bergizi atau apapun dalam kehidupannya, hidupnya yang tidak mengganggu masyarakat sekitarnya, tidak merugikan masyarakat dan menjadi beban tetapi justru memberikan manfaat. ${ }^{16}$

Penjelasan tentang ragam metode dakwah yang dapat menjadi acuan pemilihan metode dakwah yang sesuai dengan kondisi objektif mad'u pada Al-Qur'an surat an-Nahl ayat 125 , yaitu:

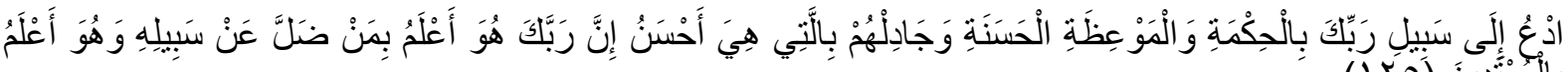

Terjemahan;

Serulah (manusia) kepada jalan Tuhan-mu dengan hikmah dan pelajaran yang baik dan bantahlah mereka dengan cara yang baik. Sesungguhnya Tuhanmu Dialah yang lebih mengetahui tentang siapa yang tersesat dari jalan-Nya dan Dialah yang lebih mengetahui orang-orang yang mendapat petunjuk.

Pada ayat tersebut, ditemukan landasan metode dakwah yang telah diperintahkan untuk dilaksanakan dalam aktivitas dakwah, metode-metode dakwah yang telah ditetapkan pada surat An-Nahl ayat $125 \mathrm{ini}$, secara garis besar terbagi atas tiga, yakni metode bi alhikmah, mauidzah hasanah, dan metode al-mujadalah. Ragam metode tersebut bila dipahami dan diaplikasikan oleh para da'i/ da'iah diharapkan mampu mewujudkan dakwah yang efektif dan efisien.

a. Metode bi Al-hikmah

\footnotetext{
${ }^{16}$ Asep Muhyiddin dan Ahmad Safei, Loc.Cit, h. 77.

${ }^{17}$ Departemen Agama RI, Loc. Cit, h. 282.
} 
Al-Hikmah menurut pendapat Ibn Faris seperti dikutip Dr. Arifuddin, M.ag. menyatakan bahwa al-hikmah berakar dari huruf-huruf ya, kaf, dan mim yang mempunyai pengertian dasar mencegah. Di tambah dengan penjelasan dari Al-Ragib Al-Asfahaniy bahwa mencegah dalam pengertian dasar tersebut berarti mencegah dengan tujuan memperoleh kemaslahatan. ${ }^{18}$

Metode bi al-hikmah adalah metode dakwah yang memiliki makna yang sangat luas namun mencakup pada bagaimana kebijaksanaan seorang aktivis dakwah dalam melaksanakan aktivitas-aktivitas dakwah. Menurut Toha Yahya Umar menyatakan bahwa;

Hikmah berarti meletakkan sesuatu pada tempatnya dengan berpikir, berusaha menyusun, dan mengatur dengan cara yang sesuai keadaan zaman dengan tidak bertentangan dengan larangan Tuhan ${ }^{19}$

Adapun pengertian al-hikmah menurut Ibn Qayyim adalah;

Mengetahui kebenaran dan melaksanakannya, baik dalam bentuk perbuatan maupun dalam bentuk perkataan. Hal itu tidak dapat direalisasikan melainkan dengan memahami Al-Qur'an, mengerti syariat Islam dan menghayati hakikat keimanan. ${ }^{20}$

Menurut Abdul Halim Mahmud seperti dikutip Muliaty Amin menyatakan bahwa hikmah adalah penempatan sesuatu pada tempatnya. ${ }^{21}$ Adapun pendapat M. Munir, dkk, yakni, apabila hikmah dikaitkan dengan dakwah, ditemukan bahwa hikmah merupakan peringatan kepada juru dakwah untuk tidak menggunakan satu bentuk metode saja. Sebaiknya harus menggunakan berbagai macam metode sesuai dengan realitas yang dihadapi dan sikap masyarakat terhadap agama Islam. ${ }^{22}$

Dakwah bi al-hikmah berarti dakwah bijak, yakni selalu memperhatikan suasana, situasi, dan kondisi mad'u. menggunakan metode yang relevan dan realistis sebagaimana tantangan dan kebutuhan, dengan memperhatikan kadar pemikiran dan intelektual, suasana psikologis, serta sosial kultural mad'u. prinsip-prinsip metode bi al-hikmah ini ditujukan

${ }^{18}$ Arifuddin, Metode Dan Strategi Dakwah Bi Al-Hikmah (Cet.1, Makassar: Alauddin University Press, 2012), h. 13.

\footnotetext{
${ }^{19}$ Wahidin Saputra, Lot.Cit, h. 245.

${ }^{20}$ Arifuddin, Op.Cit, h. 22.

${ }^{21}$ Muliaty Amin, Loc. Cit, h. 31.

${ }^{22}$ M. Munir, Dkk, Metode Dakwah Edisi Revisi ( Cet.3, Jakarta; Kencana, 2009), h. 14.
} 
terhadap mad'u yang kapasitas intelektual pemikirannya terkategorisasikan khawas, cendikiawan, atau ilmuwan. ${ }^{23}$

M. Natsir seperti dikutip Acep Aripuddin menyatakan bahwa metode bi al-hikmah adalah metode yang digunakan untuk setiap golongan baik golongan cerdik, golongan awam, ataupun golongan antara keduanya. Menurutnya metode dakwah bi al-hikmah bisa berarti hikmah dalam berbicara sesuai dengan kondisi mad'u yang dihadapi. Begitu pula hikmah dengan akhlak dan metode memberi contoh. ${ }^{24}$

Metode al-hikmah dapat dikatakan sebagai metode yang memiliki pendekatan multi metode, dimana da'i mampu bersikap dan bertindak bijaksana dalam menghadapi mad'u. Dai mampu menempatkan diri ditengah-tengah mad'u, tahu kapan dia harus bicara dan kapan harus diam. Menyesuaikan dakwah dengan kadar akal, bahasa, dan lingkungan mad'unya. Menurut Sayid Qutb, metode dakwah bi al-hikmah adalah metode dakwah yang memperhatikan keadaan dan tingkat kecerdasan mad'u serta memperhatikan kadar materi yang disampaikan agar tidak membebaninya ${ }^{25}$.

Penerapan metode dakwah dengan metode bi al-hikmah ini akan terwujud apabila memperhatikan tiga faktor, yaitu;

1) Keadaan situasi orang-orang yang didakwahi.

2) Kadar atau ukuran materi dakwah yang disampaikan agar mereka merasa tidak keberatan dengan beban materi tersebut.

3) Metode penyampaian materi dakwah dengan membuat variasi sedemikian rupa yang sesuai dengan kondisi pada saat itu. ${ }^{26}$

Beberapa uraian tersebut mengindikasikan bahwa metode bi al-hikmah adalah metode yang paling utama dalam melaksanakan aktivitas dakwah . Hal ini secara gamblang

\footnotetext{
${ }^{23}$ Asep Muhyiddin Dan Ahmad Safei, Loc. Cit, h. 79.

${ }^{24}$ Acep Aripuddin, Loc. Cit, h. 72.

${ }^{25}$ Acep Aripuddin, Ibid, h. 72.

${ }^{26}$ Asep Muhyiddin Dan Ahmad Safei, Ibid, h. 80
} 
dan sistematis serta lebih terperinci telah di uraikan oleh Arifuddin dalam bukunya. ${ }^{27}$ Penting dan keutamaan metode bi al-hikmah dalam aktivitas dakwah menggambarkan keharusan seorang aktivis dakwah untuk lebih memahami konsep bi al-hikmah sebagai persiapan untuk menghadapi mad'u yang memiliki karakteristik yang berbeda.

b. Metode Mauidzah Hasanah,

Secara bahasa mau'idzah hasanah terdiri dari dua kata, yaitu mau'idzah dan hasanah.

Kata mauidzah berasal dari kata wa'adzaya'idzu-wa'dzan-'idzatan yang berarti; nasihat, bimbingan, pendidikan dan peringatan, sementara hasanah berarti kebaikan. ${ }^{28}$

Pengertian mauidzah hasanah menurut istilah berdasarkan pendapat Abdul Hamid Al-Bilali adalah,

Al-mau'izhah hasanah merupakan salah satu manhaj (metode) dalam dakwah untuk mengajak kejalan Allah dengan memberikan nasihat atau membimbing dengan lemah lembut agar mereka mau berbuat baik. ${ }^{29}$

Senada dengan pendapat Abdul Hamid al-Bilali, Wahidin Saputra mengklasifikasikan mauidzah hasanah dalam beberapa bentuk, yaitu;

1) Nasihat atau petuah

2) Bimbingan, pengajaran (pendidikan).

3) Kisah-kisah.

4) Kabar gembira dan peringatan.

5) Wasiat (pesan-pesan positif). ${ }^{30}$

Mengkaji tentang metode mau'idzah hasanah, Arifudddin juga secara lengkap merumuskan karakteristiknya, sebagai berikut;

1) Bentuk nasihat berupa pernyataan yang disampaikan melalui bahasa lisan maupun tulisan.

2) Menggunakan bahasa persuasive dengan bahasa simpati mudah menyentuh hati dan menggugah kesadaran pihak mad'u untuk melakukan perbuatan yang makruf dan meninggalkan perbuatan mungkar.

3) Subjek atau dai memperlihatkan sikap lemah-lembut (layyin) atau penuh kasih sayang.

4) Disertai argumen-argumen yang logis, menggembirakan berupa hal-hal kenikmatan. Begitu pula di dalamnya dikemukakan izzar (informasi yang menakutkan) yang berupa siksaan yang sangat dahsyat dalam neraka. Dengan tujuan mendorong mereka Press, 2012.

${ }^{27}$ Lihat, Arifuddin, Metode dan Strategi Dakwah Bi Al-Hikmah (Makassar: Alauddin University

\footnotetext{
${ }^{28}$ Wahidin saputra, Loc. Cit, h. 251.

${ }^{29}$ M. Munir, dkk, loc. cit, h. 61.

${ }^{30}$ Wahidin saputra, op. cit, h. 252.
} 
melakukan perbuatan yang baik dan member daya potensi kepada mereka untuk meninggalkan perbuatan-perbuatan yang jelek. ${ }^{31}$

Menurut pendapat Muhammad Husain yusuf, menyatakan bahwa;

Mereka butuh kepada pelajaran yang baik (al-mauidzah al-hasanah), ucapan yang mengena (qaul baligh) serta penjelasan yang berguna berupa sugesti (targhib) untuk mengikuti kebenaran, penjelasan tentang kebaikan, mengikuti kebenaran, serta ancaman (tahrib) mengikuti kebatilan, serta penjelasan atas dosa dan nista yang terdapat dalam kebatilan. Begitu pula seterusnya sampai benar-benar jelas kepada mereka, jalan yang lurus dan cahaya yang terang, serta dapat menghilangkan keraguan mereka untuk masuk ke dalam barisan orang-orang mukmin di bawah panji nabi dan rasul yang paling mulia. ${ }^{32}$

Cara berdakwah dengan metode mauidzah hasanah berdasarkan beberapa pendapat yang telah dibahas, lebih spesifik ditujukan kepada manusia tingkat kedua yakni manusia pada umumnya, yakni mereka yang tidak sampai pada taraf kemampuan manusia jenis pertama. Secara potensial mereka memiliki fitrah kebenaran tetapi mereka selalu ragu-ragu antara mengikuti kebatilan yang selama ini tumbuh di daerah sekitarnya atau mengikuti kebenaran yang disampaikan kepada mereka. ${ }^{33}$

M.Munir, dkk. berpendapat tentang mau'idzah hasanah yakni;

kata-kata yang masuk ke dalam kalbu dengan penuh kasih sayang dan ke dalam perasaan dengan penuh kelembutan, tidak membongkar atau membeberkan kesalahan orang lain sebab kelemah-lembutan dalam menasihati seringkali dapat meluluhkan hati yang keras dan menjinakkan kalbu yang liar, ia lebih mudah melahirkan kebaikan daripada larangan dan ancaman. ${ }^{34}$

Senada dengan yang dinyatakan oleh M.Munir, dkk. Yakub menyatakan bahwa mauidzah hasanah harus memperhatikan beberapa faktor, yaitu;

1) Tutur kata yang lembut sehingga terkesan di hati.

2) Menghindari sikap tegar dan kasar.

3) Tidak menyebut-nyebut kesalahan yang telah dilakukan oleh orang-orang yang didakwahi karena boleh jadi hal itu dilakukan atas dasar ketidaktahuan atau dengan niat baik. $^{35}$

Pendapat-pendapat tentang metode mauidzah hasanah mengindikasikan bahwa

metode mauidzah hasanah mengarah pada nasihat yang baik yang berkesan dan sesuai untuk kalangan masyarakat pada umumnya yakni masyarakat kebanyakan.

${ }^{31}$ Arifuddin, Metode Dakwah Dalam Masyarakat Plural; Sebuah Penelitian Kualitatif ( Cet.1, Ciputat: Sejahtera Kita, 2012), h. 95.

${ }^{32}$ Asep Muhyiddin Dan Ahmad Safei, Loc. Cit, h. 82.

${ }^{33}$ Ibid, h. 81 .

${ }^{34}$ M.Munir, dkk., Loc. Cit, H. 17

${ }^{35}$ Asep Muhyiddin dan Ahmad Safei, loc.cit, H. 82. 


\section{c. Metode Al-Mujadalah}

Metode al-Mujadalah adalah metode ketiga yang diperintahkan dalam Al-Qur'an pada surat An-Nahl ayat 125, untuk lebih memahami bagaimana, kapan, dan dimana harus diterapkan maka perlu terlebih dahulu dipahami definisinya. Dari segi etimologi (bahasa) lafadz mujadalah terambil dari kata "jadala” yang bermakna memintal, melilit. Apabila ditambahkan alif pada huruf jim yang mengikuti wazan faa ala, "jaa dala" dapat bermakna berdebat, dan "mujadalah" perdebatan. ${ }^{36}$

Muhammad Husain Yusuf, menyatakan bahwa metode al-mujadalah ditujukan kepada manusia jenis ketiga yakni orang-orang yang hatinya dikungkung secara kuat oleh tradisi jahiliyah, yang dengan sombong dan angkuh melakukan kebatilan, serta mengambil posisi arogan dalam menghadapi dakwah. ${ }^{37}$ Adapun menurut Sayyid Muhammad Thantawi, menyatakan bahwa metode al-mujadalah adalah suatu upaya yang bertujuan untuk mengalahkan pendapat lawan dengan cara menyajikan argumentasi dan bukti yang kuat. ${ }^{38}$

Beberapa prinsip yang harus diperhatikan dalam memakai metode al-mujadalah yaitu;

1) Tidak merendahkan pihak lawan apalagi menjelek-jelekkan sehingga ia merasa yakin bahwa tujuan diskusi bukanlah mencari kemenangan, melainkan menundukkannya agar ia sampai kepada kebenaran.

2) Tujuan diskusi hanyalah semata-mata menunjukkan kebenaran sesuai dengan ajaran Islam, bukan lain-lain.

3) Tetap menghormati pihak lawan, sebab jiwa manusia tetap memiliki harga diri. ${ }^{39}$

Ketiga metode dakwah tersebut oleh Rasulullah saw diaplikasikan dalam berbagai pendekatan, seperti;

1) Pendekatan personal, yakni da'i dan mad'u langsung bertatap muka sehingga materi yang disampaikan langsung diterima dan reaksi mad'u biasanya bisa langsung diketahui.

\footnotetext{
${ }^{36}$ Wahidin Saputra, Ibid, h. 253.

${ }^{37}$ Asep Muhyiddin Dan Ahmad Safei, loc. cit, h. 82.

${ }^{38}$ M.Munir, dkk, loc.cit, h. 18.

${ }^{39}$ Asep Muhyiddin Dan Ahmad Safei, Loc.Cit, h. 84.
} 
2) Pendekatan pendidikan, yakni dakwah dilakukan beriringan dengan masuknya Islam kepada kalangan sahabat.

3) Pendekatan diskusi, biasa dilakukan dalam diskusi keagamaan dimana dai bertindak sebagai narasumber sedangkan mad'u bertindak sebagai audiens.

4) Pendekatan penawaran, pendekatan penawaran yang dilakukan oleh Nabi saw adalah ajakan untuk beriman kepada Allah swt tanpa menyekutukan-Nya dengan yang lain, dilakukan dengan metode yang tepat tanpa paksaan.

5) Pendekatan misi, yakni pengiriman tenaga da'i ke daerah-daerah di luar tempat domisili. $^{40}$

Sebagai aktivis dakwah penting mengetahui beberapa sumber-sumber metode dakwah yang dapat dijadikan rujukan atau referensi dalam berdakwah, yaitu;

1) Al Qu'ran, banyak ayat-ayat yang membahas tentang dakwah baik yang berhubungan dengan kisah para rasul dalam menghadapi umatnya maupun ayat-ayat yang ditujukan kepada nabi Muhammad saw ketika beliau melancarkan dakwahnya. Ayat-ayat tersebut menunjukkan metode yang harus dipahami dan dipelajari oleh setiap muslim.

2) Sunnah Rasul, banyak hadis-hadis yang berkaitan dengan dakwah. Begitu juga dalam sejarah hidup dan perjuangannya dan cara-cara yang beliau pakai dalam menyiarkan dakwahnya baik ketika beliau berjuang di Makkah maupun di Medinah.

3) Sejarah hidup para sahabat dan fugaha, sejarah para sahabat dan fuqaha merupakan contoh baik dan sangat berguna bagi juru dakwah.

4) Pengalaman, pengalaman seorang juru dakwah dapat dijadikan referensi ketika berdakwah, "experience is the best teacher". ${ }^{41}$

\footnotetext{
${ }^{40}$ Wahidin Saputra, Loc. Cit, h. 258.

${ }^{41}$ Wahidin Saputra, Ibid, h. 256.
} 
Setiap juru dakwah harus tetap memegang teguh prinsip-prinsip umum dari watak dan karakteristik dakwah itu sendiri, yakni;

1) Adam al-iqrah fi ad-din, yakni menghargai kebebasan dan hak asasi tiap-tiap individu.

2) Adan al-haraj, menghindari kesulitan dan kepicikan.

3) At-tadarruj, bertahap, terprogram, dan sistematis. ${ }^{42}$

Seorang aktivis dakwah diharapkan agar senantiasa tetap belajar dan berur ntuk memahami setiap aspek kehidupan baik berkaitan dengan mad'u maupun berkait. engan metodenya karena sebaik apapun materi yang diberikan kalau disampaikan deng; a yang kurang tepat dan bijak, maka dakwah itu hanya akan menemui kegagalan.

Harapan terbesar oleh seorang da'i yang benar-benar tulus dalam berdakwah adalah menghindari terjadinya kegagalan. Untuk mengantisipasi hal tersebut, maka seorang da'i harus cerdas memilih ragam metode yang dianjurkan dalam Al-Qur'an dan menerapkan dalam setiap aktivitas dakwahnya demi terwujudnya dakwah yang efektif dan efisien.

${ }^{42}$ Asep Muhyiddin Dan Agus Ahmad Safei, Loc.Cit, h. 84. 


\section{DAFTAR PUSTAKA}

Arifuddin, Metode Dan Strategi Dakwah Bi Al-Hikmah (Cet.1, Makassar: Alauddin University Press, 2012.

--, Metode Dakwah Dalam Masyarakat Plural; Sebuah Penelitian Kualitatif, Ciputat: Sejahtera Kita, 2012.

Amin, Muliaty, Teori-Teori Ilmu Dakwah (Cet.1, Makassar: Alauddin Press, 2011

Arifin, Anwar, Dakwah Kontemporer: Sebuah Studi Kontemporer, Yogyakarta: Graha Ilmu, 2011.

Acep Arifuddin, Pengembangan Metode Dakwah: Respon Dai Terhadap Dinamika Kehidupan Beragama Di Kaki Ciremai (Cet.1, Jakarta:Rajagrafindo Persada, 2011.

Ali Azis, Moh, Ilmu Dakwah, Edisi Revisi, Jakarta:Kencana, 2009.

Faizah dan Muchsin Effendi, Lalu, Psikologi Dakwah, Jakarta: Kencana, 2009

Ilaihi, Wahyu dan Polah, Harjani Hefni, Pengantar Sejarah Dakwah, Jakarta: Kencana, 2007.

Ilyas Ismail, A, dan Hotman, Prio, Filsafat Dakwah: Rekayasa membangun Agama dan Peradaban Islam, Jakarta: Kencana, 2011.

Idris, Malik, Strategi Dakwah Kontemporer, Makassar: Sarwah Press 2007

Jumantoro, Totok, Psikologi Dakwah: Dengan Aspek-Aspek Kejiwaan Yang Qur'ani, Penerbit Amzah, 2001.

Munir, M, dkk, Metode Dakwah Edisi Revisi, Jakarta; Kencana, 2009.

Muhyiddin, Asep dan Ahmad Safei, Agus, Metode Pengembangan Dakwah (Cet.1, Bandung: Pustaka Setia, 2002.

Nasional, Departemen Pendidikan, Kamus Besar Bahasa Indonesia Edisi Ketiga, Jakarta: Balai Pustaka, 2005.

RI, Departemen Agama, Al-Qur'an Dan Terjemahnya, Jakarta: Darus Sunnah, 2012.

Muhammad Said, Nurhidayat, Dakwah \& Efek Globalisasi Informasi, Makassar: Alauddin University Press, 2011.

Saputra, Wahidin, Pengantar Ilmu Dakwah (Cet. 1, Jakarta; Raja Grafindo Persada, 2011. 